\title{
Raphaël Confiant, Black is black
}

\section{Elena Pessini}

\section{OpenEdition}

\section{Journals}

\section{Édition électronique}

URL : http://journals.openedition.org/studifrancesi/8114

DOI : 10.4000/studifrancesi.8114

ISSN : 2427-5856

\section{Éditeur}

Rosenberg \& Sellier

\section{Édition imprimée}

Date de publication : 1 juillet 2009

Pagination : 454

ISSN : 0039-2944

\section{Référence électronique}

Elena Pessini, « Raphaël Confiant, Black is black», Studi Francesi [En ligne], 158 (LIII | II) | 2009, mis en ligne le 30 novembre 2015, consulté le 11 janvier 2021. URL : http://journals.openedition.org/ studifrancesi/8114; DOI : https://doi.org/10.4000/studifrancesi.8114

\section{Ce document a été généré automatiquement le 11 janvier 2021.}

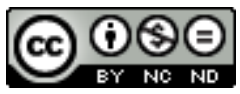

Studi Francesi è distribuita con Licenza Creative Commons Attribuzione - Non commerciale - Non opere derivate 4.0 Internazionale. 


\title{
Raphaël Confiant, Black is black
}

\author{
Elena Pessini
}

\section{RÉFÉRENCE}

RAPHAËL CONFIANT, Black is black, Monaco, Éditions Alphée - Jean-Claude Bertrand, 2008

(«Ethiopica»), pp. 263.

1 Il est précisé en couverture du dernier roman de Raphaël Confiant que le lecteur se trouve face à un "récit". Il faudrait ajouter pour être plus précis que c'est un récit qui contient un roman, Parcours d'un corps, en train de s'écrire (laborieusement) au fur et à mesure qu'avance le livre. Deux narrations s'y enchassent, l'histoire du protagoniste Abel, écrivain, qui vit des aventures rocambolesques et le texte de son roman qui l'accompagne à ce moment de son existence. La vie d'Abel se partage entre la Martinique et Paris. La Martinique, où il réussit à soudoyer de façon plus ou moins malhonnête l'héritage considérable de sa grand-mère qu'il déteste, où il rejoint les rangs d'une secte animée par un soi disant prophète, Eskrou Bilongo, qui propose à ses adeptes une régénération de la race noire à travers des rites qui ne manquent pas de faire sourire le lecteur, mais qui permettront le retour définitif en Afrique, terre mère par excellence. Et Paris, où il pense pouvoir vivre de ses rentes en compagnie de son ami Saint Martineau, professeur de mathématiques au lycée Schœlcher, et passer son temps à ne rien faire. L'espace du livre est double, les parties qui composent Parcours d'un corps alternent régulièrement avec les aventures d'Abel et le lecteur est immédiatement au courant de ce changement car les caractères et les mises en page diffèrent. Et nous retrouvons ce caractère binaire dans l'espace où se situent les aventures d'Abel auxquelles Confiant impose un rythme assez soutenu. Le roman de notre personnage écrivain n'est pas une grande réussite, ce dernier étant davantage écrit sous la pression de son éditeur parisien plutôt que sous la dictée de son inspiration. Une inspiration principalement érotique puisqu'il nous livre la chronique des aventures sexuelles d'Evita, l'Innommée, l'Étrangère, le tout dans un crescendo qui le porte sur le terrain bourbeux et délicat de la pornographie. Confiant a ici laissé libre cours à l'humour, à l'ironie, au sarcasme qu'il manie avec l'adresse que l'on sait pour 
porter un regard sans complaisance sur la société martiniquaise, ses travers, les préjugés liés à la couleur de la peau dont elle n'a pas encore réussi à se défaire même si l'esclavage est aboli depuis longtemps. La France n'en sort pas indemne pour autant; le portrait à peine masqué d'un nouveau philosophe de la capitale en train de siroter son café sous le regard admiratif des parisiens, les français qui sont incapables de distinguer un antillais d'un maghrébin, sont savamment abîmés par l'écriture décapante de Raphaël Confiant. 